HANNA KRAJEWSKA - WARSZAWA

\title{
OPRACOWYWANIE SPUŚCIZN W ARCHIWUM POLSKIEJ AKADEMII NAUK
}

Archiwum PAN od lat specjalizuje się w zbieraniu spuścizn polskich uczonych. Utworzone 1 XII 1953 roku decyzją Sekretarza Naukowego PAN posiada aktualnie ponad 500 spuścizn, z których duża część jest opracowana. Doświadczenia zdobyte przy ich porządkowaniu przełożyły się na Wytyczne opracowania archiwalnego spuścizn rękopiśmiennych. Projekt (1958) oraz Wytyczne opracowania spuścizn archiwalnych po uczonych (1990).

Wytyczne zawierają oprócz schematu porządkowania szereg uwag i propozycji. Jednym z najważniejszych problemów było stworzenie i uznanie definicji spuścizny. Według prof. Zygmunta Kolankowskiego jest to ,zespół archiwalny pochodzenia prywatnego. Stanowi ona posiadający samodzielną wartość naukową kompleks (zbiór) materiałów archiwalnych wytworzonych w toku i w związku z życiem i działalnością osoby fizycznej, reprezentującą głównie kierunki jej życia, pracy i zainteresowań. Każdy żyjący - przekonuje dalej profesor - szerszym życiem duchowym i praktycznym wiążącym go w całą mozaikę stosunków z ludźmi oraz instytucjami, organizacjami i urzędami tworzy mniej lub bardziej świadomie własne archiwum osobiste".

Nazwa spuścizna pochodzi z niemieckiego Nachlass i oznacza „całość przekazanych archiwaliów (np. dzieła, listy, dokumenty osobiste, które dotyczą jednej osoby i które pochodzą z jednego źródła. Może to być także całość aktywów i pasywów majątku osoby zmarłej”. Spuściznę wytwarzają: człowiek, firma, stowarzyszenie. Niektórzy są zwolennikami innego określenia. Profesor Alicja Kulecka przekonuje do określenia ,archiwum osobiste” bądź ,zespół archiwalny pochodzenia prywatnego".

Dawniej popularna była „spuścizna rękopiśmienna”. W języku angielskim to private papers, w rosyjskim licznyj fond.

Spuściznę pozyskuje się w formie daru, kupna albo depozytu. Przejście do państwowej instytucji nie powoduje automatycznie, że spuścizna podlegać będzie w pełni prawu archiwalnemu. Żaden sposób akcesji nie daje pełnej władzy nad dokumentami. Największą różnicą jest dostęp do dokumentacji. Zależy on przede 
wszystkim od woli ofiarodawców. Mogą oni zamknąć spuściznę albo jej część na jakiś czas, mogą zażądać od każdego użytkownika dokładnego określenia celu kwerendy bądź w jakikolwiek sposób wpływać na korzystanie z przekazanych materiałów. Niekiedy zdarzają się nawet próby wpływania na sposób opracowania spuścizny ale najczęściej udaje się je rozwiązać w trakcie porządkowania. Jeśli ofiarodawca nie wyraża specjalnej woli to wówczas dostęp do spuścizny jest w zasadzie po jej opracowaniu, co trwa na ogół kilka lat. Udostępniając dokumenty bierze się pod uwagę ustawę o ochronie danych osobowych i prawa autorskie.

Spuścizny trafiają w różne miejsca - do archiwów, bibliotek, muzeów, towarzystw i instytucji. Dużym problemem jest fakt, iż spuścizna najczęściej nie jest przekazywana w całości, ale trafia podzielona ręką twórcy, rodziny bądź przypadkowo. Tak więc archiwa czy inne instytucje posiadają tylko część kolekcji. Nigdy nie ma pewności czy mamy do czynienia z całością dokumentacji (tu ważne jest reprezentatywność materiału). Często zdarza się i tak, że spuścizna przekazywana jest w różnych partiach, co jakiś czas. Ten sposób stosowany przez rodziny opóźnia i utrudnia opracowanie papierów osobistych.

Ponieważ trudno jest stwierdzić, czy mamy do czynienia z całością spuścizny, czy tylko z jej fragmentem i nie wiadomo czy archiwista jest pierwszym, który przegląda akta dlatego też wyznaczanie granicy zespołu jest bardzo istotne. Oczywiście spuścizną nie jest pojedynczy rękopis np. pracy naukowej czy utworu literackiego. Aby spuścizna była zespołem musi być zachowana granica strukturalna polegająca na reprezentatywności zgromadzonych materiałów w stosunku do działalności oraz ich samodzielnej wartości naukowej. Wyznaczaniu granicy zespołu służy wstępny przegląd materiałów. Trzeba zapoznać się z literaturą dotyczącą twórcy, ponieważ to pozwala ustalić w jakim zakresie zgromadzone materiały są ważne dla twórcy.

Problem granicy pojawia się także w przypadku materiałów rodzinnych. Ma to swoje konsekwencje metodyczne w tym przypadku zespołem nie jest spuścizna jednej osoby ale kilku, które pozostają ze sobą w związkach rodzinnych. Uznano wobec tego, że materiały te posiadają wiele cech wspólnych z archiwaliami rodzinno- majątkowymi i wprowadzono układ schematyczno-rzeczowy, typowy dla tego rodzaju dokumentacji. Współczesne teorie archiwalne wskazują na konieczność tworzenia zespołów prostych, głównie ze względów informacyjnych ale oczywiście istnieją duże grupy materiałów wspólnych (np. Hanna i Ludwik Hirszfeldowie, Archiwum PAN).

Spuścizny stanowią źródło do badań biograficznych i genealogicznych. Są także bezcennym źródłem historycznym dla badaczy wszystkich dziedzin życia, mówią o dziejach instytucji, komisji, stowarzyszeń itp., dają unikalną perspektywę oceny historii.

W spuściznach przechowywane są również kopie bądź oryginały dokumentów państwowych i publicznych. Niekiedy jest to uzależnione od funkcji jaką pełnił uczony w życiu.

Opracowanie spuścizny wymaga od archiwisty dużych umiejętności i doświadczenia. Jedną z podstaw jest tworzenie jednostek z materiałów luźnych. Jeśli mamy papiery osobiste wybitnego uczonego to tworzymy wówczas jednostki 
możliwie małe, „niepodzielne” w sensie archiwalnym. W innym przypadku można formować jednostki zbiorcze grupujące materiały pokrewne wg.. określonego kryterium (rzeczowego, formalnego bądź chronologicznego). Jednostka może obejmować jeden rok albo więcej np. artykuły: lata od - do albo tylko jeden artykuł (jeśli jest ważny, istotny bądź obszerny). W układzie wewnętrznym jednostki stosują foliacje i nie zszywają dokumentów.

W opisie jednostki podajemy nazwę archiwum, następnie sygnaturę i nazwę zespołu (np. Wacław Sierpiński). Tytuł formułowany jest w miarę jasno i zwięźle i zawiera informacje o treści. W podtytule umieszcza się uzupełnienie tytułu, wprowadza określenie charakteru i zawartości jednostek (np. informacje o rodzajach akt, protokoły, sprawozdania uchwały wypisy), informacje o kompletności materiałów (np. fragment), nazwy instytucji i nazwiska osób współczesnych z twórcą spuścizny, wzmianki o załącznikach, wiadomości o ważniejszych elementach zawartych w jednostkach (,w tym”, „m.in”, „głównie”), odsyłane do aneksów, datę lub daty krańcowe, sposób sporządzania materiałów np. rękopis, maszynopis, druk, kserokopie), języki, forma zewnętrzna materiałów (luźne, oprawa), objętość jednostki (liczba kart ewentualnie stron).

W systematyzacji materiałów spuścizn uwzględnia się układ w grupie: tematyczny, chronologiczny, alfabetyczny albo mieszany.

Inwentarz zawiera szczegółowe spisy zawartości jednostek zbiorczych plus aneksy. We wstępie uwzględnia się życiorys twórcy, wiadomości ogólne o spuściźnie (sposób nabycia, stan zachowania, rozmiary, kompletność, sygnatury, informacje kto ją wcześniej opracowywał, charakterystyka materiałów spuścizny oraz metod ich porządkowania, uwagi końcowe (materiały wybrakowane, informacje o fragmentach spuścizn, gdzie się znajdują, bibliografia źródeł i prac wykorzystanych przy jej opracowaniu, niekiedy indeksowanie, kartoteka korespondencji prac obcych, pamiętników, wspomnień, instytucji i organizacji naukowych a także czynności końcowe - akceptacja Komisji Metodycznej, dopływy).

Przyjęta metoda opracowania jest bardzo pracochłonna. Ostatnio, zainspirowani światowymi doświadczeniami i sugestiami Naczelnej Dyrekcji Archiwów Państwowych staramy się dążyć do uproszczenia procesu opracowania min. poprzez tworzenie znacznie krótszych wstępów.

W spuściznach znajduje się wiele dokumentów niezespołowych, materiałów niearchiwalnych i innych dokumentów. Postępowanie z nimi znalazło również swoje omówienie w Wytycznych. Są to akta urzędowe (informacje o nich zawsze znajdują się w inwentarzu) i prace drukowane (książki, druki, nadbitki). W tym przypadku zachowujemy je $\mathrm{w}$ grupie materiałów związanych $\mathrm{z}$ twórczością naukowa, literacką bądź artystyczną, jeśli na marginesach są uwagi, poprawki, uzupełnienia twórcy bądź jeśli te materiały obrazują powstanie którejś z prac twórcy. W innym przypadku książki trafiają do biblioteki archiwalnej a informacje w nich umieszcza się $\mathrm{w}$ aneksie (w akcesji podajemy z jakiej spuścizny pochodzą książki).

Fotografie mające charakter warsztatowy i amatorski zachowuje się w spuściźnie, wydziela się te, które maja charakter biograficzny i umieszcza w dziale fotografii. Materiały biograficzne i fotografie zostawia się jeśli mają związek z twórca, w przeciwnym razie wydziela się do odrębnych działów, podobnie jak 
fotografię. O tych wszystkich usunięciach informuje się na wstępie i w aneksach. $\mathrm{W}$ danym dziale są również informacje skąd pochodzą dane fotografie $\mathrm{i}$ inne. Brakowanie podejmuje się bardzo rzadko, wychodząc z założenia, że materiały w spuściźnie są unikalne i niepowtarzalne. Jednak już pierwsza selekcja materiałów odbywa się poza placówką archiwalną. Spuścizna to na ogół dar a konsekwencja tego jest fakt, iż nie można narzucać darczyńcy ostrych kryteriów dotyczących przekazanych materiałów. W archiwum wydziela się: powtarzane teksty powielone i maszynopisy, niewypełnione formularze, czyste kartki papieru, zbędne obwoluty, okładki, egzemplarz tych samych artykułów czy recenzji.

W materiałach biograficznych brakuje się odcinki rentowe, potwierdzenia nadania listu, gwarancje na sprzęt i urządzenia. Tego typu materiały oddaje się rodzinie, ale często nie jest ona zainteresowana dalszym ich przechowywaniem. Dalsze decyzje dotyczące brakowania zależą od decyzji Komisji Metodycznej. Jednak różnorodność i nieprzewidywalność materiałów stanowi przeszkodę w ustalaniu ścisłych norm wartościowania.

\section{Schemat układu opracowania spuścizny}

I. Prace twórcy spuścizny

a. referaty, artykuły, opracowania jednostka $=$ jedna praca naukowa, ok. 200 stron + ew. rękopisy, maszynopisy, odbitki

- luźne fragmenty - tytuł formułowany jest na podstawie tematyki

- drobne opracowania o pokrewnej tematyce $=$ jednostka zbiorcza , aneks jeśli powyżej 3 opracowań, podaje się tytuły .Wewnątrz jednostki - układ chronologiczny wg. Następującego porządku: rękopis, maszynopis, odbitka korektorska, druk

układ w grupie - wg. specjalności naukowej lub grup tematycznych w ich obrębie: chronologia

prace nie datowane - alfabetycznie, po ostatniej pracy datowanej

b. publikacje źródłowe

$=$ jednostka(razem: przedmowa, tekst i przypisy)

c. wykłady (konspekty, teksty, skrypty)

dzieli się na jednostki chronologiczne obejmujące rok akademicki

albo - jednostki tematyczne

albo- jednostki rzeczowo-chronologiczne

(uwzględnia się uczelnie i instytucje w których uczony prowadził wykłady)

d. recenzje prac drukowanych

łączy się w jednostki zbiorcze wg. kryteriów tematycznych, chronologicznych lub alfabetycznych /wg. nazwisk autorów recenzowanych prac/

+ aneks.

układ w grupie - wg. chronologii ewentualnie alfabetycznie - wg nazwisk autorów prac recenzowanych 
e. projekty techniczne, wynalazki, patenty

— osobno jednostki dla - projektu

- wynalazku

- patentu

— wewnattrz jednostki: - projekty techniczne - wg. zasad przyjętych dla dokumentacji technicznej

- wynalazki, patenty - wg. poszczególnych spraw

- w obrębie sprawy: - chronologicznie

— układ w grupach: _ tematycznie

- chronologicznie

- topograficznie lub w sposób mieszany

f. prace popularno-naukowe (wykłady, prelekcje, artykuły)

jednostka $=$ każda pozycja bibliograficzna

drobne pozycje= jednostki zbiorcze wg. :kryteriów rzeczowych, chronologicznych lub mieszanych / np. pogadanki radiowe, odczyty, artykuły do encyklopedii, thumaczenia wierszy, prozy,

układ w grupach- jak prace naukowe

g. przemówienia okolicznościowe, wspomnienia pogrzebowe

h. prace literackie

i. tłumaczenia z języków obcych(na/ z)

j. materiały warsztatowe (zapiski, kartoteki, bibliografia, wypisy, fotografia, wycinki prasowe)

- utrzymuje się układ nadany przez twórcę

- utrzymuje się wszelkie całości połączone w sposób mechaniczny (zeszyty, zszywki, bruliony itp.)

- materiały luźne- do 200 kart

- utrzymuje się kartoteki (w pudłach np.: )

Materiał grupuje się wg. treści, bierze się układ najłatwiejszy;

— układ proweniencyjny / np. wypisy z jednego dzieła albo jednego zespo łu archiwalnego

— układ chronologiczny / notatki z jednego okresu pracy lub życia twórcy spuścizny

— układ rzeczowy/ tematyczny- np. wypisy, zapiski czy notatki do jednego tematu

- układ rzeczowo-chronologiczny/ np. notatki dot. jednego tematu albo jednego zagadnienia w porządku historycznym /

— jeśli twórca połączył materiały warsztatowe z tekstami prac naukowych pozostawiamy je

Układ w grupie - wg. układu nadanego przez twórcę (jeśli zachował)

- albo tematycznie wg. grup zagadnień

- tematy - wg. prac których były zebrane

- albo wg. proweniencji (aneks, zespół, itp.)

II. Materiały działalności twórcy spuścizny

a. organizacyjno-naukowej na uczelniach wyższych, w instytucjach, towa- 
rzystwach naukowych, na zjazdach i konferencjach naukowych

(np. korespondencja o współpracy, plany, sprawozdania, materiały konferencji, ekspertyzy, opinie, koreferaty)

- grupuje się wg. instytucji ,w ich obrębie np. zagadnień lub poszczególnych spraw chronologicznie

- w sprawy łączy się korespondencję z danej instytucji+ inne łączące się (bruliony itp.) albo ogół materiałów odnoszących się do jednej instytucji albo grupę spraw dot. jednego zagadnienia. Wszystko zależy od rozmiarów i znaczenia materiałów

Szczątkowy materiał = jednostka, materiały dotyczący związków z kilkoma instytucjami + aneks

- opracowanie jednostek - wg. poszczególnych spraw (chronologicznie)

Układ w grupie - wg instytucji, w ich obrębie spraw, których kolejność określa kryterium rzeczowe, chronologiczne albo formalne

b. dydaktyczne w szkołach, uczelniach, kursach ( programy zajęć, notatki organizacyjne, opinie i oceny uczniów, recenzje prac magisterskich, doktorskich i habilitacyjnych uczniów)

- grupuje się w jednostki wg. kryteriów rzeczowych i chronologicznych / np. plany zajęć uniwersyteckich $\mathrm{z}$ lat, materiały seminarium doktorskiego z lat..)

c. opiniowanie prac naukowych oraz działalności osób nie związanych z działalnością dydaktyczną

(oceny prac naukowych- nie uczniów, teksty prac recenzowanych włącza się do grupy VII - Materiały osób obcych).

d. zawodowej w innych instytucjach nie posiadających charakteru naukowego (gospodarczych, administracyjnych)

e. wydawniczej, redakcyjnej i opinie o pracach dla celów wydawniczych

(korespondencje, umowy, materiały wydawnicze, recenzje wydawnicze prac obcych)

f. społeczno-politycznej

g. ewentualnie innej działalności

III. Materiały biograficzne

a. autobiografia, ankiety personalne, bibliografie prac własnych

(zapiski o charakterze osobistym itp. (osobne jednostki)

albo zbiorcze np. kryteriów tematycznych, chronologicznych lub innych (np. auto życiorysy pisane w różnych okresach życia naukowego)

układ jednostki - chronologiczny albo w obrębie alfabetycznym

układ w grupie - chronologiczny

b. dokumenty osobiste(+ paszporty)

w jednostki zbiorcze wg. kryteriów rzeczowo-chronologicznych

- w uczelniach, towarzystwach (przyjęcia nominacji, odznaczenia, nagrodach, zaświadczenia)

c. dokumenty dotyczące przebiegu nauki szkolnej, studiów, pracy i działalności świadectwa szkolne, indeksy, dyplomy, układa się w jednostki zbiorcze, chronologicznie 
d. zeszyty szkolne i notatki ze studiów

e. pamiętniki, dzienniki i albumy pamiątkowe

f. dyplomy honorowe, legitymacje, gratulacje i laurki (+ adresy, telegramy - łączy się : wg. okoliczności, których dotyczy np. obchodzenie jubileuszy)

g. materiały gospodarcze i majątkowe

układa się: wd. kryteriów rzeczowych oraz chronologicznych w sprawy , na wzór akt urzędowych

h. materiały dotyczące stanu zdrowia

— łączy się w j.a. chronologiczne / np. orzeczenia lekarskie z roku..

i. świadectwa zgonu, klepsydry, nekrologi, kondolencje

- łączy się w j.a. chronologiczne / np. testament, świadectwo zgonu, klepsydry, nekrologi, rachunki z pogrzebu, kondolencje itp.)

IV. Korespondencje (e-mail)

a. wychodząca (kopie) - układ alfabetyczny

b. wpływająca - układ alfabetyczny

(+ karty, wizytówki, telegramy) np. listy od osób i instytucji

Ad a. wychodząca

- bardzo mało, niekiedy są to autentyczne listy np. M .Handelsmann do Bronisława Dembińskiego (pani Dembińskia zwróciła je p. Handelsmanowej )

— jest kartoteka ponad zespołowa (spis korespondentów w spuściznach uporządkowanych)

gdyby była tylko korespondencja - to nie będzie to spuścizna ale „zbiór korespondencji XY".

Załączniki do listów (fotografie, rękopisy, dokumenty) pozostawiamy przy listach

Układ w j.a. - alfabetyczny wg. nazwisk odbiorców lub nadawców - chronologicznie

itp. ,układ w grupie- alfabetyczny

V. Materiały o twórcy zespołu

a. życiorysy i wspomnienia

b. bibliografia prac zestawiona przez osoby trzecie

c. recenzje o jego pracach, polemiki opracowuje się jako odrębne jednostki albo zbiorcze.

Kryteria rzeczowe: np. wzmianki i recenzje o pracy pt : , ,

Kryteria chronologiczne: wzmianki prasowe o twórcy spuścizny z lat ...

VI. Materiały rodzinne (rodowe)

Układ w grupie- zgodny z chronologią pokoleń

Dokumenty dotyczące poszczególnych członków rodziny

- materiały majątkowe

- materiały osobowe

VII. Materiały osób obcych

- sygnalizuje się je w indeksie

- zwraca uwagę we wstępie

- są niepodzielne 
Utrzymuje się w j.a wg. osób albo zbiorcze .Układa się alfabetycznie - potem chronologicznie albo rzeczowo np. prof. Stanisław Helsztyński otrzymał spuściznę literacką Stanisławy Przybyszewskiej - została wydzielona . Na ogół się zachowuje też np.: mapy druki ulotne)

VIII. Załączniki

Opracowanie spuścizny trwa dhugo i jest bardzo czasochłonne. W zamian za to czytelnik otrzymuje szczegółowy inwentarz z ogromną ilością informacji.

\section{Bibliografia}

Wytyczne opracowania archiwalnego spuścizn rękopiśmiennych. Projekt, oprcowanie pod kierunkiem Z. Kolankowskiego, Warszawa 1958.

Wytyczne opracowania spuścizn archiwalnych po uczonych. Opracowanie H. Dymnicka-Wołoszyńska, Z.Kolankowski , Warszawa 1990.

Z. Kolankowski, Podstawowe zagadnienia metodyczne porzadkowania spuścizn rękopiśmiennych, „Biuletyn Archiwum PAN”, 1959, s. 10-31

Z.Kolankowski, Granice spuścizny archiwalnej, „Archeion”, 57 (1972) s. 53-73.

H.Dymnicka-Wołoszyńska, Prace metodyczne nad ustaleniem zasad porzadkowania spuścizn archiwalnych, „Biuletyn Archiwum PAN”, 1990, s. 7-11.

A. Kulecka, Podstawowe problemy opracowania spuścizn po uczonych $w$ Archiwum PAN w ciagu ostatniej dekady (1991-1999), „Biuletyn Archiwum PAN”, 2000, s. 3-13. 